\title{
Eksistensi Rumah Baca Bagi Komunitas Selaras Alam
}

Rika Jufriazia Manita *)

Insitut Agama Islam Negeri

Batusangkar, Sumatera Barat, Indonesia

Email:

rikajufriaziamanita@iainbatusangkar.ac.id

\section{Nurmayasari}

Insitut Agama Islam Negeri

Batusangkar, Sumatera Barat, Indonesia

Email: nurmayasari161298@gmail.com
*) Corresponding Author

Kata Kunci : Existence, Rumah Baca Selaras Alam, Community.
Abstrak: Keberadaan rumah baca sangat membantu dalam memenuhi kekurangan jasa perpustakaan umum. Rumah Baca Selaras Alam yang merupakan bagian dari Perpustakaan Umum kehadirannya memberikan warna tersendiri bagi masyarakat Nagari Lasi untuk memperoleh informasi yang mereka butuhkan. Sarana Prasarana yang ada di Rumah Baca Selaras Alam sangat bermanfaat dalam pemenuhan kebutuhan masyarakat Nagari Lasi yang haus akan ilmu pengetahuan dan informasi. Rumah Baca Selaras Alam merupakan tempat berdiskusi, dan tempat perkumpulan bagi masyarakat Nagari Lasi. Penelitian ini merupakan penelitian lapangan dengan metode deskriptif kualitatif. Hasil pembahasannya adalah 1) kelembagaan di Rumah Baca Selaras Alam tidak terstruktur dan tidak efektif, hal ini dilihat dari pembagian tugas dilakukan ketika melaksanakan kegiatan. 2) koleksi yang ada di rumah baca kurang memadai dan perlu adanya penambahan koleksi. 3) pendanaan di Rumah Baca Selaras Alam diperoleh dari swadaya masyarakat. 4) hari libur sekolah merupakan jadwal kunjungan terbanyak dari Komunitas Selara Alam ini. 5) kendala yang dihadapi di rumah baca adalah tidak memiliki tenaga profesional yang memiliki latar belakang pendidikan ilmu perpustakaan.

Abstract: The existence of the rumah baca is very helpful in meeting the shortage of public library services. Rumah Baca Selaras Alam being part of the Public Library provides its own color for the people of Nagari Lasi to obtain the information they need. The infrastructure in Rumah Baca Selaras Alam is very useful in meeting the needs of the Nagari Lasi' society especially for science and information. Rumah Baca Selaras Alam is a place for making discussion and also gathering place for the people of Nagari Lasi. This research is a field research with descriptive qualitative method. The results of the discussion are 1) the institution in Rumah Baca Selaras Alam is unstructured and ineffective, it can be seen from the division of tasks carried out when carrying out activities. 2) the collections in the rumah baca are inadequate and there is a need for additional collections. 3) funding Rumah Baca Selaras Alam is obtained from non-governmental organizations. 4) school holidays are the most visited by the Selara Alam Community. 5) the obstacle from rumah baca is limited professional employees with library educational background. 


\section{PENDAHULUAN}

Perpustakaan merupakan sebuah tempat penyediaan beragam informasi, awalnya koleksi perpustakaan berbasis karya cetak atau disebut juga dengan berbasis kertas. Kumpulan buku ini disimpan untuk bahan bacaan sebagai sarana belajar dan dipergunakan untuk keperluan penelitian, selain itu dijadikan sebagai pusat informasi dalam rangka mengembangkan ilmu pengetahuan dan teknologi. Jenis koleksi tercetak diantaranya adalah buku, terbitan berseri, majalah, laporan, pamplet, prosiding, dan manuskrip (naskah tulisan tangan). Sedangkan koleksi perpustakaan lainnya adalah karya rekam yang merupakan hasil pemikiran manusia tidak dalam bentuk tercetak tetapi dalam bentuk karya lain seperti rekaman suara, gambar hidup dan rekaman video, bahan grafika serta karya dalam bentuk elektronik.

Kehadiran perpustakaan di tengahtengah masyarakat sangat dibutuhkan, karena fungsi utama dari sebuah perpustakaan adalah menyediakan informasi bagi kepentingan masyarakat luas. Setiap pemustaka pasti memiliki kebutuhan yang berbeda-beda, informasi yang mereka butuhkan dapat ditemukan di perpustakaan. Selain itu, perpustakaan mempunyai peran aktif dalam memberikan perubahan serta meningkatkan kecerdasan dalam membangkitkan kesadaran masyarakat untuk mengantisipasi perubahan di masa yang akan datang. Taman Baca Masyarakat (TBM) merupakan jenis perpustakaan umum dalam skala kecil dimana pengelolanya dilakukan oleh masyarakat. Menurut Undang-Undang RI No. 43 tahun 2007 tentang perpustakaan umum pasal 22 ayat 4 masyarakat dapat menyelenggarakan perpustakaan umum untuk memfasilitasi terwujudnya masyarakat pembelajar sepanjang hayat.

TBM hadir sebagai tempat baca dengan suasana yang sederhana dan terbuka bagi siapa saja yang ingin memanfaatkannya. Hal tersebut juga tidak lepas dari peranan pemerintah setempat untuk mengembangkan TBM diwilayahnya, seperti dinyatakan dalam Undang-Undang nomor 43 tahun 2007 bab XIII pasal 49 tentang pembudayaan kegemaran membaca; "Pemerintah, pemerintah daerah, dan masyarakat mendorong tumbuhnya taman bacaan masyarakat dan rumah 
baca untuk menunjang pembudayaan kegemaran membaca."

TBM pada hakikatnya memiliki fungsi yang hampir sama dengan perpustakaan, sehingga untuk memperjelas pemahaman tentang TBM dan perbedaannya dengan perpustakaan sebaiknya melihat kembali pengertian perpustakaan menurut Undang-Undang nomor 43 tahun 2007 dalam Bab I Pasal I angka 1 yang menyatakan bahwa; "Perpustakaan adalah institusi pengelola koleksi karya tulis, karya cetak, dan/atau karya rekam secara profesional dengan sistem yang baku guna memenuhi kebutuhan pendidikan, penelitian, pelestarian, informasi dan rekreasi para pemustaka."

Menurut Kemendikbud dalam Petunjuk Teknis Pengajuan dan Pengelolaan Taman Bacaan Masyarakat tahun 2002 adalah; Lembaga pembudayaan kegemaran membaca masyarakat yang menyediakan dan memberikan layanan di bidang bahan bacaan, berupa: buku, majalah, tabloid, koran, komik dan bahan multimedia lain, yang dilengkapi dengan ruangan untuk membaca diskusi, bedah buku, menulis, dan kegiatan literasi lainnya, dan didukung oleh pengelola yang berperan sebagai motivator.

Berdasarkan pemaparan teori diatas dapat disimpulkan bahwa ada perbedaaan dan persamaan terkait Perpustakaan dengan Taman Bacaan Masyarakat, dimana antara Perpustakaan dan Taman Bacaan Masyarakat sama-sama bertujuan untuk menyediakan dan memberikan informasi kepada masyarakat/atau pemustaka yang datang berkunjung baik itu dengan menghadirkan kegiatan-kegiatan yang menunjang kreatifitas dari masyarakat tersebut. Misalnya dengan mengadakan kegiatan literasi. Dari segi perbedaan dapat dilihat dari pengelolaannya, dimana pengelola perpustakaan adalah orangorang profesional yang latar belakangnya memiliki ilmu perpustakaan. Sedangkan untuk TBM pengelolanya adalah masyarakat biasa, hanya sebagai pemotivasi, mendukung ataupun sebagai pendorong (motivator).

Dilihat dari berbagai aspeknya Perpustakaan dikelola dengan sistem yang terstuktur, sedangkan TBM sebagai social cultural artinya membudayakan membaca dengan 
memanfaatkan koleksi yang ada dan saling bertukar pikiran. Sehingga dengan adanya Perpustakaan dan TBM ini dapat melahirkan masyarakat yang cerdas, yang terdapat dalam UndangUndang Dasar 1945 yaitu mencerdaskan kehidupan bangsa.

UU No 20 tahun 2003 telah menjelaskan bahwa pendidikan di selenggarakan dengan mengembangkan budaya membaca, menulis, dan berhitung bagi segenap warga masyarakat. Salah satu upaya yang telah dilakukan oleh pemerintah dalam rangka meningkatkan minat baca masyarakat adalah dengan memberikan dorongan kepada masyarakat untuk mendirikan Taman Baca Masyarakat dalam memenuhi kebutuhan membaca dan meningkatkan minat baca masyarakat. Beberapa warga masyarakat telah berpartisipasi dalam pendirian Taman Bacaan Masyarakat dengan membentuk komunitaskomunitas untuk memenuhi kebutuhan masyarakat terhadap informasi dengan menyediakan bahan bacaan yang bisa diakses secara cepat, mudah dan murah.

Rumah Baca Selaras Alam terletak di Nagari Lasi, Kabupaten Agam,
Provinsi Sumatra Barat. Rumah Baca Selaras Alam berada dibawah Komunitas Selaras Alam. Komunitas ini mendirikan rumah baca dengan tujuan sebagai sarana belajar bagi masyarakat Nagari Lasi sekaligus untuk meningkatkan minat baca masyarakat. Rumah Baca Selaras Alam berdiri sejak tahun 2019. Berbagai macam kegiatan sudah dilakukan oleh Komunitas Selaras Alam dalam rangka meningkatkan Eksistensi Rumah Baca Selaras Alam di tengah-tengah masyarakat.

Observasi awal peneliti lakukan ke Rumah Baca Selaras Alam adalah bahwasanya Rumah Baca Selaras Alam sudah memiliki bangunan sendiri berbentuk Rumah Adat Sumatera Barat yang terbuat dari bambu. Keadaan rumah baca terkait sarana dan prasarana maupun koleksi yang ada di Rumah Baca Selaras Alam dapat dikatakan sudah memadai terlihat dengan beragamnya koleksi yang ada.

Penulis melakukan penelitian di Rumah Baca Selaras Alam dengan alasan Rumah Baca Selaras Alam terletak di tengah perkampungan yang mudah dijangkau dari berbagai penjuru. Rumah Baca Selaras Alam 
langsung dikelola oleh Pendiri Komunitas Selaras Alam yang bernama Bapak Suardi Mahmud yang merupakan Pensiunan Guru yang menjunjung tinggi pendidikan. Agar masalah penelitian lebih terfokus maka peneliti membatasi masalah penelitian pada segi kelembagaan, koleksi, pendanaan, kegiatan, jumlah pengunjung, perkembangan, perpustakaan, masalah yang dihadapi, serta upaya yang dilakukan dalam mendukung eksistensinya sebagai sumber belajar.

\section{METODE PENELITIAN}

Metode penelitian yang digunakan dalam penelitian ini adalah penelitian lapangan dengan metode deskriptif kualitatif dengan tujuan menggambarkan, meringkaskan berbagai kondisi atau berbagai variabel. Lexy Moleong menjelaskan bahwa jenis penelitian deskriptif adalah penelitian yang datanya dikumpulkan berupa kata-kata, gambar dan bukan angka. Sugiyono (2012) juga menjelaskan bahwa Metode penelitian kualitatif sering disebut dengan penelitian naturalistik karena penelitiannya dilakukan dalam kondisi alamiah.
Dari penjelasan diatas dapat ditarik kesimpulan bahwa tujuan penelitian kualitatif ini adalah untuk mencari makna konstektual secara menyeluruh berdasarkan fakta-fakta (tindakan, ucapan, sikap dan pikiran) dari subjeksubjek penelitian yaitu mencari kebenaran menurut pandangan yang diteliti di lapangan. Dalam penelitian ini, penulis menggunakan Penelitian Deskriptif Kualitatif. Tempat penelitian ini berada di Nagari Lasi Kecamatan Candung Kabupaten Agam.

Menurut Sugiyono (2018) dijelaskan bahwa teknik yang digunakan dalam pengumpulan data terbagi 2 yaitu Pertama Observasi Terus Terang Atau Tersamar. Observasi Terus Terang Atau Tersamar yaitu dalam melakukan pengumpulan data peneliti menyatakan keterusterangannya kepada narasumber bahwa peneliti sedang melakukan penelitian. Jadi, narasumber sejak awal sudah mengetahui tentang aktivitas penelitian. Kedua Wawancara Semi terstruktur, jenis wawancara ini sudah termasuk dalam kategori in-dept interview, dimana dalam pelaksanaannya lebih bebas bila dibandingkan dengan wawancara 
terstuktur. Tujuan wawancara jenis ini adalah untuk menemukan permasalahan sacara terbuka, di mana pihak yang diajak wawancara dimintai pendapat dan ide-idenya.

Peneliti terjun langsung kelapangan untuk memperoleh data sebagai bukti dari keabsahan data. Dengan observasi dan wawancara yang peneliti lakukan ini, sangat banyak informasi dan pengetahuan ataupun ide yang peneliti dapat dalam penunjang penelitian ini. Peneliti selalu mengamati kegiatan yang dilaksanakan di Komunitas Selaras Alam baik itu secara langsung maupun tidak secara langsung. Selain itu peneliti juga mengajukan pertanyaan-pertanyaan dalam menambah dan memperoleh informasi yang dibutuhkan.

\section{HASIL DAN PEMBAHASAN}

\section{Kelembagaan}

Secara definitif organisasi adalah wadah dari kegiatan dan aktivitas sumber daya manusia dalam upaya mencapai tujuan. Menurut Siagian dalam buku Hartono (1994) organisasi adalah setiap bentuk perserikatan antara dua orang atau lebih yang bekerja sama untuk mencapai tujuan dan terikat secara formal dalam suatu hierarki dimana selalu terdapat pimpinan dan seseorang atau sekelompok orang yang disebut bawahan. Pengorganisasian merupakan proses penyusunan struktur organisasi yang sesuai dengan tujuan organisasi, sumber daya yang dimilikinya serta ruang lingkupnya.

Aspek utama dalam proses penyusunan struktur organisasi adalah departementalisasi dan pembagian kerja. Departementalisasi merupakan pengelompokan kegiatan-kegiatan kerja suatu organisasi agar dapat dikerjakan bersama. Sedangkan pembagaian kerja adalah perincian suatu tugas suatu pekerjaan agar setiap individu dalam organisasi bertanggungjawab dan melaksanakan sekelompok kegiatan. Kedua aspek ini merupakan dasar suatu pengorganisasian untuk mencapai tujuan yang telah ditetapkan secara efisien dan efektif, Hartono (1994).

Bapak Suardi Mahmud adalah pendiri Komunitas Selaras Alam yang berada di Nagari Lasi, Kecamatan Candung, Kabupaten Agam. Komunitas Selaras Alam ini berdiri sejak tahun 2009 dengan visinya yaitu 
terwujudnya masyarakat yang humanis yang selaras dengan alam dan bertaqwa kepada Allah. Tujuan pendirian Komunitas Selaras Alam ini selain menjaga kelestarian alam juga meningkatkan perekonomian masyarakat Nagari Lasi dengan memberikan pembinaan dan pelatihan kepada masyarakat dalam hal bertani dan berkebun khususnya dalam pembudidayaan kopi lasi. Aktivitas yang berkaitan dengan kependidikan, pengelolaannya dilakukan oleh Rumah Baca Selaras Alam.

Selain pendiri Rumah Baca Selaras Alam, Bapak Suardi Mahmud dibantu oleh para anggota yang sudah terdaftar pada komunitas Selaras Alam dalam pengelolaan Rumah Baca. Kepanitiaan pelaksanaan kegiatan disusun ketika akan mengadakan sebuah kegiatan. Hal ini dilakukan karena anggota Komunitas Selaras Alam memiliki kesibukan dan aktifitas yang berbedabeda. Seluruh kegiatan di kelola oleh Ketua Komunitas Selaras Alam yang dibantu oleh Sekretaris dalam pengelolaannya, kemudian sekretaris yang menyampaikan informasi kepada seluruh anggota terkait kegiatan yang akan dilakukan, seperti: rapat kelompok, diskusi dan lainnya. Contoh kegiatan yang dilakukan di Komunitas Selaras Alam adalah Babuko Basamo. Pada acara Babuko Basamo ini juga dilakukan musyawarah dan diskusi bersama terkait perkembangan komunitas, juga membahas kegiatan lain yang akan dilakukan di Komunitas Selaras Alam. Anggota Komunitas Selaras Alam berjumlah 50 orang.

Berikut model kepanitiaan pada acara Babuko Basamo yang dilakukan Komunitas Selaras Alam.

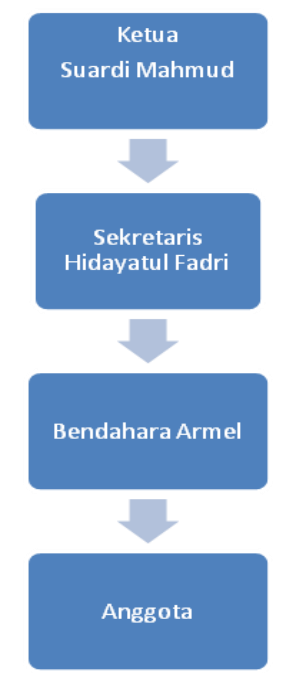

\section{Koleksi}

Sebenarnya koleksi perpustakaan desa secara umum sama saja dengan jenis koleksi untuk perpustakaan lainnya. Mulai dari koleksi jenis buku, koleksi cetak bukan buku seperti majalah, jurnal, dan laporan penelitian. Koleksi yaitu sumber-sumber informasi 
di perpustakaan yang telah terorganisir sehingga dijadikan bahan bacaan, bahan ajar dan referensi bagi pemustaka yang membutuhkannya Pawit M. Yusuf (2010). Koleksi yang ada di Rumah Baca Selaras Alam adalah buku perkebunan kopi, pertanian, lingkungan hidup, sejarah, ilmu pengetahuan dan untuk anak-anak disediakan karya sastra cerpen dan novel, dongeng dan lainnya.

Koleksi ini berasal dari sumbangan Masyarakat. Masyarakat Nagari Lasi yang berkunjung ke Rumah Baca Selaras Alam beragam mulai dari anakanak yang kegemarannya adalah membaca buku dongeng dan buku cerita sambil menikmati hari libur sekolah. Para Ibu-Ibu dan BapakBapak lebih suka berdiskusi di Rumah Baca Selaras Alam sambil membaca buku-buku yang berhubungan dengan pertanian dan perkebunan. Jumlah pengunjung yang datang ke Rumah Baca juga tidak menentu, hal ini dikarenakan aktivitas dan kesibukan masyarakat. Diwaktu libur pengunjung Rumah Baca Selaras Alam cukup ramai.

Hartono (2015) menjelaskan bahwa Koleksi perpustakaan adalah seluruh bahan pustaka yang dimiliki, atau dikumpulkan, diolah, dan disimpan dengan menggunakan sistem tertentu oleh perpustakaan untuk disebarluaskan kepada masyarakat guna memenuhi kebutuhan informasi mereka.

\section{Pendanaan}

Hartono (2015) berpendapat bahwa anggaran atau dana merupakan aspek penting untuk keberlangsungan Perpustakaan. Pendanaan dan anggaran perpustakaan sangat penting, yaitu untuk menjamin agar perpustakaan memperoleh bagian yang adil dari anggaran. Sedangkan menurut Sumantri (2006) menjelaskan bahwa agar perpustakaan dapat berfungsi dengan sebaik-baiknya diperlukan pembiayaan yang cukup, seperti untuk pengadaan koleksi dan pengadaan peralatan. Umumnya dana untuk Perpustakaan sulit didapat. Namun, hal ini harus tetap diupayakan agar kelangsungan perpustakaan dapat terjamin. Dengan pengelolaan yang baik, anggaran perpustakaan dapat dihimpun dan dimanfaatkan sebaikbaiknya.

Dari kedua pendapat diatas dapat ditarik kesimpulan bahwa jika tidak 
ada dana ataupun anggaran perpustakaan maka perpustakaan tidak dapat beroperasi dengan baik. Sedangkan dana disini sangat berperan penting dalam memenuhi kebutuhan pemustakanya.

Pendanaan Rumah Baca Selaras Alam ini berasal dari swadaya masyarakat. Dana yang ada di Komunitas Selaras Alam ini dipergunakan untuk memenuhi seluruh kegiatan yang ada di Komunitas Selaras Alam dalam memenuhi kebutuhan informasi. Komunitas Selaras Alam memiliki perbendaharaan yang handal dalam mengatur keuangan komunitasnya. Walaupun dana komunitas murni dari swadaya masyarakat tanpa adanya bantuan dari pemerintah, komunitas ini bisa mengelola dana yang dimiliki untuk melaksanakan kegiatan yang sudah dilakukan.

Kehadiran Rumah Baca Selaras Alam sangat membantu masyarakat dalam membenahi keuangan keluarga dan kebutuhan akan kecerdasan intelektual masyarakat. Kenapa dikatakan begitu, karena selain kegiatan literasi yang dilakukan, masyarakat juga dibekali dengan keterampilan perkebunan salah satunya adalah dengan pembudidayaan tanaman kopi di kebun-kebun masyarakat. Masyarakat Nagari Lasi memiliki harapan kedepannya dengan adanya Koperasi di Komunitas Selaras Alam ini.

\section{Kegiatan yang ada di Komunitas Selaras Alam}

Menurut Sumantri (2006) kegiatan yang dilakukan dalam memasyarakatkan perpustakaan adalah: Bimbingan pembaca, Melalui TV, Menyebarkan poster, brosur, dan lainlain, Mengadakan kegiatan lomba, Penyuluhan/ Penataran, Pameran buku, dan Papan pengumuman.

Teori yang dijabarkan oleh Sumantri tidak jauh berbeda dengan kegiatan yang ada di Perpustakaan dengan kegiatan yang ada di Rumah Baca Selaras Alam. Adapun kegiatan yang telah dilakukan Komunitas Selaras Alam diantaranya adalah: Kegiatan Gotong Royong bersama, diskusi dengan masyarakat, Lomba baca puisi dan dongeng (story telling) juga mengenalkan budaya minangkabau kepada masyarakat tentang cara memainkan alat musik talempong dan musik saluang. 
Komunitas yang dirintis oleh dengan memulai menanam kayu di Bapak Suardi Mahmud ini sangat hutan sebelum penanaman kopi.

memberikan motivasi kepada Tercatat sudah 50 anggota masyarakat dalam hal menjaga komunitas dengan beragam aktivitas, kelestarian alam dengan diantaranya adalah dengan melakukan pembudidayaan tanaman kopi di lereng diskusi seperti diskusi tentang UU Gunung Merapi. Disamping menjaga Desa No. 6 tahun 2014: Desa atau desa kelestarian alam, budidaya kopi ini adat, diskusi tentang hak-hak dan juga dapat meningkatkan kehidupan perlindungan petani yang dilakukan di dan menambah income pendapatan Rumah Baca Selaras Alam. Selain itu masyarakat. Bapak Suardi Mamud juga dilakukan pelatihan-pelatihan terinspirasi untuk membuat komunitas pertanian seperti pembudidayaan Selaras Alam ini karena latar belakang tanaman kopi yang dimulai dari kehidupan masyarakat Nagari Lasi pembibitan, penanaman, pemanenan yang mayoritas adalah petani yang dan pemasaran. Dalam pemasaran kopi, bergantung pada keadaan musim. Suardi Mahmud terjun langsung dalam Masyarakat bisa bercocok tanam di pengelolaan pasar kopi yang ada di sawah pada saat musim penghujan. Nagari Lasi yaitu dengan cara membeli Pada musim kemarau lahan-lahan kopi yang sudah di keringkan kepada pertanian tidak dapat diolah karena masyarakat. Kopi kering tersebut di kekurangan air, suhu yang panas olah oleh Bapak Suardi Mahmud yang membuat hutan di wilayah Nagari Lasi kemudian dipasarkan ke kafe dan menjadi kering. Bukan saja diwilayah warung-warung kopi yang ada di Nagari Lasi akan tetapi wilayah sekitar juga merasakan efek dari kekeringan ini. Beranjak dari kejadian tersebut pensiunan Guru ini merasa terpanggil hatinya untuk membantu masyarakat dengan cara mendirikan Komunitas Selaras Alam. Langkah awal yang dilakukan oleh Suardi Mahmud adalah Sumatera Barat dan Jawa.

Kegiatan yang paling banyak dilakukan di Rumah Baca Selaras Alam adalah di hari libur yaitu pada hari sabtu dan minggu. Pada hari libur inilah yang menjadi puncak kunjungan ke Rumah Baca Selaras Alam. Remaja dan anak-anak suka mendatangi Rumah 
Baca Selaras Alam sekedar mencari bahan bacaan ringan sambil rekreasi karena lokasi Rumah Baca Selaras Alam sangat sejuk dan memiliki pemandangan yang sangat indah. Bahkan ada pengunjung yang sengaja membawa perlengkapan lukis dari rumah sekedar untuk menyalurkan hobi mereka. Selain itu pengunjung juga bisa mempelajari tentang pembibitan tanaman kopi. Para pengunjung bisa ikut dalam melakukan pembibitan. Dengan demikian para pengunjung mendapatkan pengetahuan tentang tata cara pembibitan kopi.

\section{Jumlah Pengunjung}

Istilah pemustaka sebenarnya baru resmi dipakai setelah diundangkannya Undang-Undang Tentang Perpustakaan Tahun 2007. Dalam Undang-Undang tersebut dinyatakan bahwa yang disebut dengan "pemustaka" adalah pengguna perpustakaan, yaitu perseorangan, kelompok orang, masyarakat, atau lembaga yang memanfaatkan fasilitas layanan perpustakaan dalam buku Fransisca Rahayuningsih (2015).

Pengunjung Rumah Baca Selaras Alam berasal dari masyarakat Nagari Lasi pada umumnya. Selain itu, Rumah
Baca Selaras Alam juga sering dikunjungi oleh anak-anak, pelajar, mahasiswa dari daerah sekitar Nagari Lasi seperti dari Padang, Batusangkar dan Payakumbuh untuk belajar. Jumlah kunjungan ke Rumah Baca Selaras Alam tidak menentu. Jadwal kunjungan terbanyak biasanya di hari libur sekolah.

\section{Perkembangan Perpustakaan}

Berawal dari seorang Guru yang menjunjung tinggi pendidikan Bapak Suardi Mahmud mendirikan Komunitas Rumah Baca Selaras Alam ini. Melihat ekonomi dan kurangnya informasi yang didapat oleh masyarakat maka Pensiunan Guru ini merasa terpanggil jiwanya untuk membangun Nagari Lasi dengan mendirikan Rumah Baca di Bawah Naungan Komunitas Selaras Alam. Keberadaan Rumah Baca Selaras Alam memberikan warna baru bagi masyarakat dalam hal pencarian informasi. Melalui Rumah Baca ini maka Bapak Suardi Mahmud beserta teman-temannya memberikan pemahaman kepada warga tentang pentingnya pelestarian lingkungan khususnya pelestarian alam karena alam adalah pusat penyimpanan air. 
Dalam hal mengembangkan taman bacaan hal utama yang dilakukan oleh pengelola taman bacaan adalah dengan melakukan sosialisasi ketengah-tengah masyarakat. Sosialisasi yang dilakukan oleh Komunitas Selaras Alam adalah dengan cara mengundang para tokoh masyarakat pada forum-forum diskusi yang dilaksanakan di Komunitas Selaras Alam.

Kegiatan-kegiatan yang dilakukan di Komunitas Selaras Alam memberikan hal yang positif bagi masyarakat Nagari Lasi. Dengan adanya Komunitas Selaras Alam pengelolaan informasi di Nagari Lasi berkembang secara pesat. Ilmu pengetahuan masyarakat semakin bertambah, ekonomi masyarakat menjadi makmur dan pola pikir masyarakat sudah lebih terarah terutama dalam hal pendidikan anakanak mereka, yang pada awalnya pendidikan anak-anak di Nagari Lasi pada tingkat Sekolah Menengah Atas sekarang sudah banyak yang melanjutkan pendidikannya ke tingkat yang lebih tinggi lagi.

\section{Masalah Yang Dihadapi Komunitas Selaras Alam}

Adapun masalah yang temukan di Komunitas Rumah Baca Selaras Alam antara lain:

Pertama, Pengelola Rumah Baca Selaras Alam memiliki latar belakang yang bukan dari lulusan ilmu perpustakaan melainkan dari disiplin lmu lain. Kedua: Tidak adanya pembagian tugas di Komunitas Selaras Alam. Dan ketiga: Tidak adanya bantuan dana dari pemerintah sehingga pengelolaan Rumah Baca kurang optimal.

\section{Upaya Yang Dilakukan Dalam Mendukung Eksistensinya Sebagai Sumber Belajar}

Adapun upaya yang dilakukan dalam mengatasi masalah guna mendukung eksistensi antara lain:

Pertama, guna menunjang eksistensi Komunitas Rumah Baca Selaras Alam maka pihak pendiri dapat bekerja sama dengan berbagai TBM, tukar-menukar informasi, melakukan kegiatan promosi TBM guna lebih dikenal orang banyak, mengikuti pelatihan yang berhubungan erat dengan perpustakaan.

Kedua, membekali berbagai pengetahuan dan ilmu serta 
pengalaman kepada masyarakat di berbagai bidang, terakhir penambahan Koleksi Rumah Baca Selaras Alam khususnya koleksi pertanian dan perkebunan yang dapat dimanfaatkan oleh masyarakat untuk meningkatkan ilmu pengetahuan.

\section{KESIMPULAN}

Berdasarkan hasil penelitian dan pembahasan terhadap "Eksistensi Rumah Baca Komunitas Selaras Alam Di Nagari Lasi Kecamatan Candung Kabupaten Agam" dapat ditarik beberapa kesimpulan: (1) Kelembagaan yang ada di Komunitas Selaras Alam tidak efektif karena tidak adanya pembagian tugas dari awal Komunitas ini terbentuk, apabila Ketua Komunitas memiliki keperluan maka Rumah Baca Selaras Alam ditutup, (2) Koleksi yang ada di Rumah Baca Selaras Alam belum memenuhi kebutuhan masyarakat khususnya masyarakat Nagari Lasi, selain itu pendanaannya berasal dari swadaya masyarakat sehingga pengembangan koleksi di Rumah Baca Selaras Alam menjadi susah dan memakan waktu yang lama, (3) Pengelola Rumah Baca Selaras
Alam tidak memiliki latar belakang ilmu perpustakaan.

Saran: (1) Ketua Komunitas Selaras Alam sebaiknya melakukan pembagian tugas kepada anggota Komunitas sehingga pengelolaan Rumah Baca Selaras Alam dapat dilakukan dengan maksimal, (2) untuk penambahan koleksi Rumah Baca sebaiknya ada dana khusus sehingga ketika pengembangan Koleksi dilakukan Pembina Rumah Baca tidak kebingungan dalam pencarian dana, (3) Pengelola Rumah Baca Selaras Alam sebaiknya memiliki latar belakang ilmu perpustakaan sehingga bisa mengelola Rumah Baca dengan baik.

\section{REFERENSI}

Damayani, Ninis Agustini, dkk. 2017. Pengembangan Taman Bacaan Masyarakat Di Desa Sindangkerta Kecamatan Cipatujah Kabupaten Tasikmalaya. Dharmakarya: jurnal Aplikasi Ipteks Untuk Masyarakat Universitas Padjajaran.http://jurnal.unpad. ac.id/dharmakarya/article/view/1 4869. Diakses pada tanggal 26 Februari 2020.

Departemen Pendidikan Nasional. UU No. 20 Tahun 2003 tentang Sistem Pendidikan Nasional. 
Hartono. 2015. Dasar-Dasar Manajemen Perpustakaan : Dari Masa Ke Masa. Malang: UIN-Maliki Press.

J Moleong, Lexy. 2006. Metodologi penelitian kualitatif. Bandung: Remaja Rosdakarya.

Rahayuningsih, Fransisca. 2015. Mengukur Kepuasan Pemustaka : Menggunakan Metode LibQual+ $+\mathrm{TM}$

Yogyakarta: Graha Ilmu.

Rahmawati, Ratih, dkk. 2012. Perpustakaan Untuk Rakyat: Dialog Anak dan Bapak. Jakarta: Sagung Seto.

Sugiyono. 2012. Metode Penelitian Kuantitatif, Kualitatif $R \& D$. Bandung: Alfabeta.

Sugiyono. 2018. Metode Panelitian Manajemen Pendekatan: Kuantitatif, Kualitatif, Kombinasi (Mixed Methods), Penelitian Tindakan (Action Research), Penelitia Evaluasi). Bandung: Alfabeta.

Sumantri. 2006. Panduan Penyelenggaraan

Perpustakaan Sekolah. Bandung: Remaja Rosdakarya.

Perpustakaan Nasional RI. 2009. Undang-undang RI Nomor 43 Tahun 2007 Tentang Perpustakaan. Jakarta: Tamita Utama.

Yusuf, Pawit M., Subekti, Priyo. 2010.

Teori \& Praktik Penelusuran
Informasi (Information Retrieval). Jakarta: Kencana Prenada Media Group. 